\title{
The status of the Dactylorhiza incarnata populations in the Kalba Altai, Kazakhstan
}

\author{
ALEVTINA N. DANILOVA ${ }^{\nu}$, AIDAR A. SUMBEMBAYEV ${ }^{* \nu}$ \\ Botanical Garden, 1, Ermakov street, Ridder City, 070000, East Kazakhstan Region, Republic of Kazakhstan. \\ Tel. 877-77917337, ^email: a-n-danilova@yandex.ru, •vemail: aydars@list.ru \\ Manuscript received: 18 May 2021. Revision accepted: 13 July 2021.
}

\begin{abstract}
Danilova AN, Sumbembayev AA. 2021. The status of the Dactylorhiza incarnata populations in the Kalba Altai, Kazakhstan. Biodiversitas 22: 3180-3195. The article provides a botanical description of the current state of populations of threatened species Dactylorhiza incarnata (L.) Soo in the Kalba. The ecological analysis of the flora, the ecological optimum of the species, the vitality of plant communities, and the degree of anthropogenic load are presented in the research. On the basis of field surveys, four main populations were identified in 13 typical plant communities. Flora of plant communities of $D$. incarnata on the Kalba Ridge includes 117 species belonging to 30 families and 80 genera. The ecological optimum of $D$. incarnata can be spotted on the southeastern slopes with diffused lighting and moderate wind impact. The plant communities with optimal conditions are Filipendulo-SanguisorboThalictrosum and Carexoto-Equiseto-Filipendulo-Festucosum characterized by highly humid meadows and forest edges with low density and competition. Self-maintenance and reproduction of the species are fulfilled mainly by seeds, less often by vegetative reproduction of the finger root. Due to analysis of the age composition of populations and the dynamics and stability of plant communities the recovery index is within the optimum. Typical indicator species are Thalictrum simplex L., Salix viminalis L., Filipendula ulmaria (L.) Maxim., Sanguisorba officinalis L., Geranium pratense L., Festuca pratensis Huds.
\end{abstract}

Keywords: Kazakhstan Altai, Orchidaceae, plant community, route-reconnaissance, variability

Abbreviations: IVC: index of vitality of plant community; PC: plant community

\section{INTRODUCTION}

The protection and conservation of rare and endangered plant species in general, and species of the Orchidaceae family (Givnish et al. 2015; Khapugin 2020), in particular, is impossible without the development of species protection strategies. For this purpose, extensive research is being carried out on Dactylorhiza and closely related genera on the territory of Kazakhstan and neighboring territories (Hedrén 2001; Zheleznaya 2009; Kaki et al. 2020; Shirokov et al. 2020; Braunschmid et al. 2021).

At present, Kazakhstan indicates the growth on its territory of 30 species (Kubentayev et al. 2021), including 11 species in the flora of Kalba Altai (Sumbembayev et al. 2020). The development of a scientifically based orchid conservation system in the Kalba Altai is one of the priority tasks of preserving the biological diversity of the Republic of Kazakhstan.

Dactylorhiza incarnata (L.) Soo. is characterized as rare, meadow-boggy (Scmeidt 1996; Efimov 2020), skiogeliophyte (Shipunov and Efimov 2015), hygrophytic (Efimov et al. 2016), tuber-lobed perennial with a Eurasian (Paleoarctic) range. This entomophilous orchid (Naczk et al. 2018) is the obligated mycosymbiotroph (Paun et al. 2011; Wani et al. 2021). It is a large plant (Shipunov et al. 2004) with a strong stem, numerous, large, lanceolate leaves and a dense inflorescence containing up to 40 flowers (Shipunov and Bateman 2005, Akbulut et al, 2020). It highly varies in traits (Füller 1972; Juskiewicz-
Swarczyna et al. 2006; Naczk et al. 2016, Brandrud 2020), even within the same population (Pillon et al. 2006; Swarts and Dixon 2009). It can form dense clusters but also it can exist as single individuals (Nevzorov 2019; Efimov 2020). It typically grows on calcareous soils (Bateman and Rudall 2006), but it can often be found also in communities with other orchid species (Pillon et al. 2007; Jersáková et al. 2015; Balao et al. 2017). According to IUCN (2020), Dactylorhiza incarnata is a species with least concern and with wide geographical range (Balao 2017). In Ireland, they exist in small numbers and they are susceptible to destruction by reducing their specific places of growth (Hedrén et al. 2011). It can grow both in undisturbed plant communities and in places with a high recreational load (Schrautzer et al. 2011). Populations with the participation of the species are usually very dynamic (De Hert et al. 2012; Naczk et al. 2015). They are adapted to flat areas (Shipunov and Bateman 2005).

The species is a tuberous plant with an elongated shoot (Wróblewska et al. 2019). Tuberoid exists for about one and a half years. The species is of great scientific interest as a rare, ornamental, and medicinal plant (Vallius et al. 2007; Tsiftsis et al. 2008; Nordström and Hedrén 2009; Shirokov et al. 2017; Popovich 2020).

Despite the poverty of the species diversity of orchids in Kazakhstan, all of them are of high scientific interest and they remain poorly studied, especially in mountainous regions (Kotukhov et al. 2018; Sumbembayev et al. 2020). The studies of the current state of $D$. incarnata populations 
and the cenotic structure of communities are necessary to establish the ecological optimum of the species under the conditions of the Kalba Ridge, floral similarity of communities, age composition and self-maintenance of populations.

The aim of this study was to survey botanical and ecological of Dactylorhiza incarnata populations on the Kalba Ridge, and to determine of the vitality and ecological plasticity of the species in the examined populations based on the similarities and differences of plant communities. The main tasks were to determine the structure of the ontogenetic composition of the species and the degree of regeneration, to establish the floristic composition of communities, to analyze the ability of the species that existed in different types of communities, to determine the main limiting factors.

\section{MATERIALS AND METHODS}

Survey area is Kalba ridge. The ridge is massive as it stretches in the west-north-west direction for 200-230 km with a width of 50-70 km. The heights gradually increase from west to east from 400 to 1606 meters above sea level (m.a.s.l.). The relief of Kalba is low-mountainous, mainly steep-slope, in places low-mountain-valley (kazgeo.ucoz.org).

The survey of the Kalba Altai was fulfilled by using the route-reconnaissance method, covering the entire territory of the Kalba ridge. Four expeditionary surveys were carried out in different periods of the growing season of the species. The studies were performed in Kokpekty, Ulan, Zharma administrative regions, Kazakhstan during 20182020. Geographically, the routes of the expeditions passed through the territory of the Kalba Altai, along the eastern forest (Koktau mountains, Sibin depression) and western steppe parts (Karazhal mountains, Saryzhol ridge) of the Kalba ridge covering the valleys of the Tainty, Laila, Irtysh, Urunghai, Kokpekty, Shar, Sibin lakes.

Locations were mapped using Qgis 3.12.0-București software (https://download.qgis.org). Statistical processing of the results was carried out in Statistica 64-10 (StatSoft). The population similarity of the studied populations was calculated using the Jaccard formula (Jacccard 1901). The synanthropization coefficient was calculated using the Ilminskikh method (Ilminskikh and Zhukov 2020). The assessment of the vitality composition of plant communities was carried out using two methods: the method for determining the vitality of plant communities (Q) by Zlobin (1989) and the Vitality Index (IVC) proposed by Ishbirdin and Ishmuratova (2004). The family structure is indicated according to the Takhtajan (2009). Species and genera in families are arranged alphabetically. Latin names are given according to WCSP (2020) and The Plant List (2020). The abundance of species in phytocenoses was determined using the Drude abundance scale (Drude 1913).

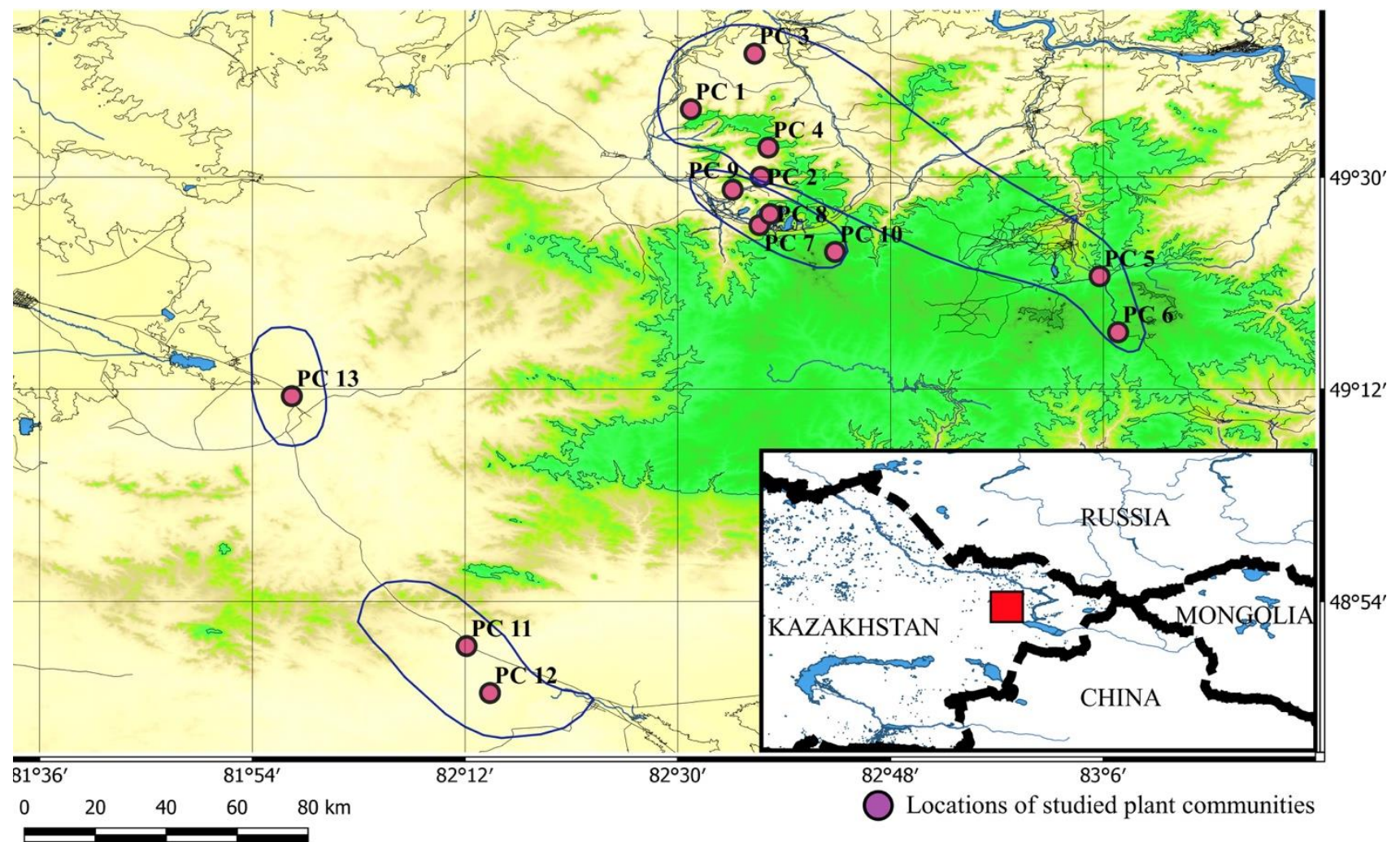

Figure 1. Discovered plant communities of Dactylorhiza incarnata in the Kalba Ridge (marked with violet points) 
Table 1. Characteristics of the locations of Dactylorhiza incarnata plant communities (PC)

\begin{tabular}{|c|c|c|c|}
\hline $\begin{array}{c}\text { Name of the plant community } \\
\text { and its locality }\end{array}$ & Ecological confinement & $\begin{array}{cc} & \text { The } \\
& \text { number of } \\
\text { Area, pre- } & \text { presative } \\
\mathbf{m}^{2} & \begin{array}{c}\text { generative } \\
\text { individuals } \\
\text { per } 10 \mathrm{~m}^{2}\end{array}\end{array}$ & Indicators of vitality of plant community \\
\hline
\end{tabular}

\section{Koktau population \\ Carexo-menthuosum}

(Carex macroura Meinsh., Mentha asiatica Boriss), PC1

Filipendulo-SanguisorboThalictrosum

(Filipendula ulmaria (L.) Maxim., Sanguisorba officinalis L., Thalictrum minus L.), PC 2

\section{Scirpo-Poesum}

(Scirpus sylvaticus L., Poa palustris L.), PC 3

\section{Heteroherbo-gramisum}

(Elytrigia repens (L.) Nevski, Poa angustifolia L., Fragaria virides (Duch.) Weston, Ranunculus acris L., Galium verum L.), PC 4

\section{Filipendulo-Equisetosum}

(Filipendula ulmaria (L.) Maxim., Equisetum arvense L.), PC 5

\section{Deschampsio-Carexosum}

(Deschampsia cespitosa (L.) Beauv., Carex humilus Leyss.), PC 6

\section{Sibin population}

Carexo-Calamagrostosum

(Carex disticha Huds, Calamagrostis epigeous (L.) Roth.), PC 7

\section{Sanguisorbo-Carexosum}

(Sanguisorba officinalis L., Carex disticha Jacq.), PC 8

Deschampsio-Alliosum

(Deschampsia cespitosa (L.) Beauv., Allium shoenoprasum L.), PC 9
The foot of the northwestern slope, the valley of a mountain stream, heavily overgrown with tree and shrub species. Stones covered with a thin layer of moss.

Meadow glade, covered from all sides by pine trees (Pinus sylvestris L.). In small groups, in abundantly moist, exposed areas.

Glade in a hollow with excessive moisture on abundantly humic mountain meadow chernozems.

A ridge on closed mattress granitoids, well protected from wind and insolation from the southwest direction (Pinus sylvestris L., Populus laurifolia Ledeb.)

Forb-grass community. A narrow strip in the coastal part of the southwestern slope.

In the valley of the stream, in the composition of forb meadows. A hollow with a leaking spring.
Water meadows. The species is 100 located in small groups along the stream valley.

Open flooded forb meadows.

Damp meadows and excessively wet forest edges
2

17 generative individuals. Young, poorly progressing, capable of self-maintenance by seed and vegetative means, stably holding its territory.

50 generative individuals. Normal type, with a left-sided spectrum, actively progressing, multiplying both by seed and vegetative way.

10 generative individuals. Incomplete, right-sided, aging, with poor seed reproduction, it faces strong competition from Scirpus sylvaticus L. for the covered area, which is the main reason for poor seed reproduction.

316 generative individuals. Plant community is weakened, wilting, but with good renewal. It has no possibility of settling new territories because it is experiencing competition from other species. Population recovery is possible in case of a decrease in anthropogenic load.

26 generative individuals. Plant community is depressed and weakened. Individuals vegetate poorly and bear fruit. Seed reproduction prevails; young individuals are concentrated around the mother plant.

4120 generative individuals. Plant community is full-membered, progressive, with a left-sided spectrum. Renewal occurs both by seed and vegetative way.

540 generative individuals. Poorly progressive, leftsided spectrum, aging, but with satisfactory renewal. Despite strong oppression and competition in the phytocenosis, the plant community tends to conquer new territories.

$7 \quad 110$ generative individuals. Full-term, with a leftsided spectrum, with a sufficient degree of renewal. Despite the difficult conditions, the species is actively progressing.

218 generative individuals. The state of the plant community is normal. The species stably occupy new territories. The ecological amplitude of the species is low. Renewal is consistently high. 


\begin{tabular}{|c|c|c|c|}
\hline $\begin{array}{l}\text { Equiseto-Carexosum } \\
\text { (Equisetum pratense } \text { Ehrh., } \\
\text { Carex juncella (Fries) Th. } \\
\text { Fries), PC } 10\end{array}$ & $\begin{array}{l}\text { An herb community on a moist, } 80 \\
\text { gentle slope, protected by } \\
\text { thickets from the southwest } \\
\text { Betula rezniczenkoana (Litv.) } \\
\text { Schischk., Salix pentandra L., } \\
\text { S. rosmarinifolia L., Salix } \\
\text { bebbiana Sarg., Salix } \\
\text { pyrolifolia Ledeb. }\end{array}$ & 5 & $\begin{array}{l}30 \text { generative individuals. Plant community of } \\
\text { normal type, full-length, left-sided, progressive, } \\
\text { with high renewal. }\end{array}$ \\
\hline
\end{tabular}

\section{Kokpekty population \\ (Medicago falcata L., \\ Thalictrum simplex L., Dactylis \\ glomerata L., Festuca pratensis \\ Huds.), PC 11 \\ Carexo-Equiseto-Filipendulo- \\ Festucosum \\ (Carex juncella (Fries) Th. \\ Fries, Equisetum pratense \\ Ehrh., Filipendula ulmaria (L.) \\ Maxim., Festuca pratensis \\ Huds.), PC 12}

Medicago-Dactylo-Festucosum River valley, under the canopy 1

\section{Kalbatau population \\ Equiseto-Carexosum}

(Equisetum pratense Ehrh, Carex juncella (Fries) Th.

Fries), PC 13
Salix viminalis L., S. tenuijulis

Ledeb., Betula humilis Schrank.

A herb-grass meadow, in places 50 protected by a canopy of shrubs and Betula humilis Schrank.
A damp herb meadow, in a

650 wide strip along the southwestern border of the tree and shrub massif.
100

5

45 generative individuals. The plant community is actively progressing, with a left-sided spectrum, full-member, with high seed renewal. Capable of capturing new territories downstream.

$5 \quad 17$ generative individuals. Resilient, slow-growing communities with high density and competition. The ecotype reproduces mainly by seeds, it has a high regeneration.
The following factors were determined for each plant community: the number of generative and vegetative individuals, the height of generative shoots, the number of leaves on the generative shoots, the length of the peduncle, the number of leaves per individual, the size of the inflorescence, and the number of flowers Each trait was studied on 20 plants in each plant community during the flowering period.

According to expeditionary surveys, four main populations were identified (Figure 1, Table 1), named after the geographical location: Koktau, Sibin, Kokpekty, Kalbatau. Thirteen plant communities were recorded in different ecological and phytocenotic conditions (wet meadows, flooded forb meadows, damp, excessively wet meadows, steppe moderately moist forb-sedge-grass meadows, mossy placers of stones among woody-shrub vegetation).

\section{RESULTS AND DISCUSSION}

Despite the spatial isolation of populations, Dactylorhiza incarnata (L.) Soo grows in similar ecological conditions. The need to combine the optimal number of required factors hinders the ability to further resettle. $D$. incarnata is one of those species that critically endure anthropogenic influences, including haymaking before the seed-ripening phase, trampling by livestock, and pulling out for bouquets. The populations of the species require not only a comprehensive study but also the development of protective measures to protect the growing areas.

\section{Koktau population}

Koktau population is located in the eastern part of the Kalba ridge, in the southern and southwestern parts of the ancient Koktau mountains at altitude of 600-800 m.a.s.l. The population occupies sporadic loci in mountainmeadow meso-hygrophytic plant communities. The main typical habitats are mossy stones in the valley of mountain streams or rivers, less often on gravelly or swampy banks. Plots have full or diffuse lighting, less often full shading. The wind impact is strong throughout the year. The vegetation cover is diverse in terms of species and it is composed of 88 species. The most numerous are such families: Poaceae (17\%), Asteraceae (9\%), Rosaceae $(11 \%)$, Ranunculaceae $(11 \%)$, and Fabaceae $(5 \%)$. By the nature of life forms in the composition of the plant community, the share of herbaceous species is $87 \%$, and the share of tree and shrub species is $13 \%$. In ecological terms, the mesohygrophytic species in the Koktau population predominate $(75 \%)$, while the mesophytes $(16 \%)$ and the xeromesophytes $(9 \%)$ constitute an insignificant part. The synanthropization coefficient is $36 \%$, which indicates a significant degree of anthropogenic load. 
On the territory of the Koktau population, there were identified 6 spatially isolated plant communities of various types of phytocenoses differing in ecological conditions and floristic composition.

Carexo-Menthuosum (Carex macroura Meinsh., Mentha asiatica Boriss.) plant community (PC1) is located at an Eastern part of the Kalba ridge, Koktau, Shat tract, $49.595833^{\circ} \mathrm{N}, 82.518611^{\circ} \mathrm{E}, 634$ m.a.s.l. Plant community is located in single individuals along the valley of a small mountain stream.

The vegetation cover is arranged in mosaics. Due to the low density of the location of individuals and species the layering in the herbage is not clearly expressed. Among the dominant species it is important to note Mentha asiatica Boriss.-cop, located on bumps formed from Carex macroura Meinsh.-cop.

In general, the mint-sedge plant community can be characterized as young, poorly progressing, capable of selfmaintenance by seed and vegetative means, stably holding its territory.

The ecological conditions for the habitation are quite optimal. This site meets the requirements of the species in terms of illumination, moisture, altitude. D. incarnata prefers to inhabit moss-sedge cushions rich in humus litter and abundant litter. Excess moisture is essential as it is the manifestation of the life strategy of the species.

As the limiting factor, it is important to mention the regular movement of livestock across the stream in the areas of settlement of $D$. incarnata. An anomaly was found on some flowering individuals (splitting of the lip of the flower): instead of 3 lobes, individuals with a 5-membered lip are found.

In the initial description, it was established that the state of the species in the population is not threatened; moreover, the species may well disperse and occupy new territories in similar ecological areas downstream.

Filipendulo-Sanguisorbo-Thalictrosum (Filipendula ulmaria (L.) Maxim., Sanguisorba officinalis L. Thalictrum minus L.) plant community (PC2). It is located in the upper limit of the southeastern slope of the Koktau mountains in the eastern part of the Kalba ridge in the Taldy tract, $49.500278^{\circ} \mathrm{N}, 82.616944^{\circ} \mathrm{E}, 859$ m.a.s.l. Description was made during the flowering period.

The species is located in a meadow glade, covered from all sides by pine trees (Pinus sylvestris L.).

Phytocenosis composition is polydominantic. The grass stand is quite dense, without noticeable bald spots. The total coverage of the phytocenosis is about 95\%. D. incarnata does not play a significant role in the composition of the phytocenosis; the studied species accounts for $1.6 \%$ of the community.

The studied species steadily occupy a place in this community. D. incarnata prefers to settle in small groups, in abundantly wet, bare areas, less often in dense grass. The existing habitat conditions are completely optimized for the species: constant moisture, well-humified soils. The age composition is dominated by young individuals in the immature and virginal stages of growth, creating diffuse spots, which indicates a fairly good renewal. Generative individuals form closely-spaced groups in the form of mosaic spots which differ in the color of the inflorescences. Most individuals are dominated by variations from dark pink to purple.

Plant community is of normal type, with a left-sided spectrum, actively progressing, multiplying by both seed and vegetative way.

The main limiting factors for this locus are uncontrolled cattle grazing, haymaking before the fruiting phase, rather strong competition in the phytocenosis and narrow ecological confinement. The anthropogenic influence on phytocenosis is extremely negative: overgrazing, plucking flowering shoots into bouquets, haymaking before the fruiting phase of inflorescences.

Genetic abnormalities were found within this plant community. For instance, a light purple color instead of purple rarely appears. Among other abnormalities, it was discovered that the two upper leaves have purple border.

Scirpo-poesum (Scirpus sylvaticus L., Poa palustris L.) plant community (PC3) is placed in a clearing in a hollow with excessive moisture; $49.674444^{\circ} \mathrm{N}, 82.608333^{\circ} \mathrm{E}, 862$ m.a.s.l. Vegetation in phytocenosis is represented exclusively by hygrophytic and mesophytic species.

Due to the heterogeneity of the relief of the site, the layering in the phytocenosis is not expressed. The dominant species are Scirpus sylvaticus L, Poa palustris L.

Dactylorhiza incarnata is scattered over the area as single individuals. The flowers are well-formed, light purple. D. incarnata has very low regeneration with a right-sided age spectrum. It rarely shows up vegetative propagation by planting several young tubers.

In general, the plant community of $D$. incarnata can be characterized as incomplete, right-sided, aging, with weak seed reproduction. It is important to note the strong competition of the species with Scirpus sylvaticus L. for the area covered, which is the main reason for the weak seed reproduction.

Heteroherbo-gramisum (Elytrigia repens (L.) Nevski, Poa angustifolia L., Fragaria virides (Duch.) Weston, Ranunculus acris L., Galium verum L.) plant community (PC4). It occupies an oblong ridge-like area, $49.541667^{\circ} \mathrm{N}$, $82.627778^{\circ} \mathrm{E}, 860 \mathrm{~m}$.a.s.l. Individuals of $D$. incarnata (L.) are strongly depressed. For the most part, there are dominated vegetative individuals in the juvenile and immature stages of growth.

The plant community can be characterized as weakened, withering, but with good regeneration. A favorable humidified first half of summer and a dry, depressing second half represent them. The main limiting factor is grazing as it can lead to trampling. It is important to note the partial stagnation of water in the spring months which outcome damping of the roots. This plant community of $D$. incarnata does not have the ability to colonize new territories and is competing with other species. With a decrease in anthropogenic load, population recovery is possible. 
Table 2. Leading flora families of Dactylorhiza incarnata populations by the number of species

\begin{tabular}{lccc}
\hline \multirow{2}{*}{ Family } & \multicolumn{2}{c}{ Flora of populations $D$. incarnata } & Flora of the Kalba ridge \\
\cline { 2 - 4 } & Number of genera from total & Number of species from total & Number of species, \% of total \\
\hline Ranunculaceae Juss. & $6 / 7.5$ & $10 / 8.5$ & $52 / 4.01$ \\
Caryophyllaceae Juss. & $2 / 2.5$ & $3 / 2.5$ & $51 / 3.94$ \\
Salicaceae Mirb. & $2 / 2.5$ & $9 / 7.7$ & $26 / 2.01$ \\
Rosaceae Juss. & $8 / 10$ & $11 / 9.4$ & $58 / 4.47$ \\
Fabaceae Lindl. & $8 / 10$ & $9 / 7.7$ & $95 / 7.33$ \\
Apiaceae Lindl. & $4 / 5$ & $5 / 4.27$ & $39 / 3.01$ \\
Asteraceae Bercht. and J. Presl. & $9 / 11.25$ & $11 / 9.4$ & $188 / 14.51$ \\
Lamiaceae Martinov & $3 / 3.75$ & $3 / 2.5$ & $43 / 3.32$ \\
Cyperaceae Juss. & $2 / 2.5$ & $5 / 4.27$ & $44 / 3.39$ \\
Poaceae Barnhart & $14 / 17.5$ & $20 / 17.1$ & $123 / 9.49$ \\
Total & $58 / 72.5$ & $86 / 73.34$ & $719 / 55.52$ \\
\hline
\end{tabular}

Filipendulo-Equisetosum (Filipendula ulmaria (L.) Maxim., Equisetum arvense L.) plant community (PC5) is located on the left bank of the Taininka river and it forms a forb-grass community in the eastern part of the Kalba ridge, in the Tsarskaya Valley tract, $49.359722^{\circ} \mathrm{N}$, $83.095^{\circ} \mathrm{E}, 977 \mathrm{~m}$.a.s.l. Plants are placed in a narrow strip in the coastal part of the southwestern slope.

The grass stand is well developed. The dominants are Equisetum arvense L.-sp, Dactylis glomerata L.-sp, Bromopsis inermis (Leyss.) Holub-sp, Filipendula ulmaria (L.) Maxim.--op 1 .

Plant community is depressed and weakened. Reproduction is realized only by seeds, with young individuals, as a rule, which are concentrated around the mother plant. The reason for this phenomenon is the good development of the mycelium of the mycorrhizal fungus. Strong competition in the plant community, complete shading, unsuitable substrate with a high content of gravel, high drainage of the soil, which does not contribute to moisture retention from habitat conditions far from optimal. Individuals of Dactylorhiza incarnata are completely covered by grass stand up to $1.0-1.2 \mathrm{~m}$ in height. During spring floods, the plant community is completely underwater for an extended period of time.

Deschampsio-Carexosum (Deschampsia cespitosa (L.) Beauv., Carex humilus Leyss.) plant community (PC6) occupies a small hollow with a flowing stream. Phytocenosis of $D$. incarnata is located in the eastern part of the Kalba ridge on the Umysh mountain pass. The species is dispersed in small dense patches along the stream valley as part of forb meadows, $49.280556^{\circ} \mathrm{N}$, $83.121111^{\circ} \mathrm{E}, 1230$ m.a.s.l. The dominants are Deshampsia cespitosa (L.) Beauv.-sp, Carex humilis Leyss.-sp, Dactylorhiza incarnata (L.) Soo-sol-sp.

Individuals of $D$. incarnata reproduce by seed and vegetative way. The vegetative method accounts for $1.5 \%$ of reproduction in the population. The color palette of inflorescences varies from light purple to dark purple.

The plant community can be characterized as full-term, progressive, with a left-sided spectrum. Renewal occurs both by seed and in a vegetative way.
The conditions for habitation of the species in the phytocenosis are only partially optimal. The species is developing quite well but there have been identified numerous diseases. The main limiting factors are diseases, excess moisture, and dense herbage. Trampling by cattle prevails among anthropogenic factors.

\section{Sibin population}

Sibin population of $D$. incarnata is located in the eastern part of the Kalba ridge, in the southwestern part of the Sibin depression. In the absence of competition, it occupies vast glades in depressions. Individuals are often settled in small but dense groups, often forming clonal families. The main habitats of the species are flooded forb meadows, excessively humid forest edges and damp glades. Vegetation cover is composed of 48 species. The main life form are herbaceous plants $(81 \%)$, woody-shrub species account for $19 \%$. The most numerous in terms of species are the following families: Poaceae (19\%), Salicaceae $(13 \%)$, Ranunculaceae $(8 \%)$, Asteraceae $(6 \%)$, Rosaceae $(6 \%)$, Apiaceae $(6 \%)$, Cyperaceae $(5 \%)$, Fabaceae (5\%). In terms of ecological confinement, the dominant part is made up of mesophytic species (67\%) and mesohygrophytic species $(27 \%)$, the smaller part is xeromesophytic species $(6 \%)$. The synanthropization coefficient of $39 \%$ indicates a significant degree of anthropogenic load. According to the floristic composition and dominant species, there have been identified four main types of phytocenoses within the Sibin population.

Carexo-Calamagrostosum (Carex disticha Huds, Calamagrostis epigeous (L.) Roth.) plant community (PC7) is located on the southwestern periphery of the Sibin depression. The species occupy flooded meadows. The soil is excessively moist, with an abundant accumulation of water on the surface, $49.431944^{\circ} \mathrm{N}, 82.615278^{\circ} \mathrm{E}, 782$ m.a.s.l. The grass stand is quite well-formed, with total coverage of $80-100 \%$. The height structure is indecipherably three-layered. 
Table 3. Characteristics of vitality and vitality type of plant community (PC) of Dactylorhiza incarnata

\begin{tabular}{|c|c|c|c|c|c|c|c|}
\hline \multirow{2}{*}{$\begin{array}{l}\text { Number of } \\
\text { PC }\end{array}$} & \multirow{2}{*}{$\begin{array}{l}\text { Vitality index of } \\
\text { PC (IVC) }\end{array}$} & \multicolumn{3}{|c|}{$\begin{array}{c}\text { Share of individuals by } \\
\text { class, \% }\end{array}$} & \multirow{2}{*}{$\begin{array}{l}\text { The degree of prosperity or } \\
\text { depression of the } \mathrm{PC},\left(\mathrm{I}_{\mathrm{Q}}\right)\end{array}$} & \multirow{2}{*}{$\begin{array}{c}\text { Quality } \\
\text { index }(\mathbf{Q})\end{array}$} & \multirow{2}{*}{$\begin{array}{l}\text { Vitality type of } \\
\text { PC }\end{array}$} \\
\hline & & $\mathbf{A}$ & b & c & & & \\
\hline 1 & 1.07 & 36 & 43 & 21 & 1.88 & 5.5 & Prosperous \\
\hline 2 & 1.17 & 20 & 46.7 & 33.3 & 0.99 & 5 & Equilibrium \\
\hline 3 & 1.22 & 28 & 57 & 15 & 3 & 6 & Prosperous \\
\hline 4 & 1.09 & 20 & 20 & 60 & 0,33 & 3 & Depressive \\
\hline 5 & 0.90 & 50 & 0 & 50 & 0,5 & 4 & Depressive \\
\hline 6 & 1.33 & 46.2 & 30.8 & 23.1 & 1.66 & 5 & Prosperous \\
\hline 7 & 0.79 & 55 & 18 & 27 & 1.35 & 4 & Prosperous \\
\hline 8 & 0.69 & 20 & 0 & 80 & 0.125 & 1.5 & Depressive \\
\hline 9 & 1.14 & 10 & 15 & 75 & 0.17 & 2.5 & Depressive \\
\hline 10 & 0.94 & 27 & 18 & 55 & 0.41 & 3 & Depressive \\
\hline 11 & 1,03 & 20 & 30 & 50 & 0,5 & 3 & Depressive \\
\hline 12 & 1,55 & 40 & 40 & 20 & 2 & 6 & Prosperous \\
\hline 13 & 0,93 & 28.5 & 28.5 & 43 & 0.66 & 4 & Depressive \\
\hline
\end{tabular}

Note: Quality index $(\mathrm{Q}): \mathrm{Q}=1 / 2(\mathrm{a}+\mathrm{b})>\mathrm{c}$-prosperous plant communities; $\mathrm{Q}=1 / 2(\mathrm{a}+\mathrm{b})=\mathrm{c}-$ equilibrium plant communities; $\mathrm{Q}=1 / 2$ $(\mathrm{a}+\mathrm{b})<\mathrm{c}$-plant communities. $\mathrm{I}_{\mathrm{Q}}=(\mathrm{a}+\mathrm{b}) / 2 \mathrm{c}$. A number of individuals ranked by the index is divided into three classes-a (high vitality), $\mathrm{b}$ (medium), and c (low)

The state of $D$. incarnata is depressed due to excessive stagnation of water. The stand is too dense for normal development $D$. incarnata. Reproduction is good: 5 vegetative individuals per $10 \mathrm{~m}^{2}$, but the age composition is dominated by generative individuals. Probably, haymaking in the fruiting phase has an impact. Color variations of inflorescences range from light pink to purple.

The plant community of the reed-sedge phytocenosis can be characterized as weakly progressive, with a leftsided spectrum, aging, but with satisfactory renewal. Despite the strong oppression and competition in the phytocenosis, the population strives to conquer new territories. The main limiting factors are competition with other species, stagnant water, pulling out for bouquets and haymaking in the fruiting phase.

Sanguisorbo-Carexosum (Sanguisorba officinalis L., Carex disticha Jacq.) plant community (PC8) is located in the southwestern outskirts of the Sibin depression. Location coordinates are $49.447778^{\circ} \mathrm{N}, 82.630278^{\circ} \mathrm{E}, 791$ m.a.s.l. The species occupy open flooded forb meadows.

The herbage is dense, well developed, the layering is not expressed. The dominant species are Carex disticha Jacq.-cop ${ }_{1}$, Sanguisorba officinalis L. (vegetative shoots)sp-cop $1, D$. incarnate-sp, Ranunculus acris L.-sp. D. incarnata plants are stunted, stocky, with narrow leaves. Browning of leaves was noted in all the individuals. Plant community can be characterized as full-member, with a left-sided spectrum and a sufficient degree of renewal. Despite the difficult conditions, the species is actively progressing. Constant stagnation of water and strong insolation during the entire growing season are the limiting factors.

Deschampsio-Alliosum (Deschampsia cespitosa (L.) Beauv., Allium shoenoprasum L.) plant community (CP9) is located in the eastern part of the Kalba ridge, in the southeast of the Sibin depression. $49.481944^{\circ} \mathrm{N}$, $82.5775^{\circ} \mathrm{E}, 782 \mathrm{~m}$.a.s.1. Plant community occupies damp meadows and overly humid forest edges.

In economic terms, this territory is used for hayfields, while in the fall period as pastures. The grass stand is very poor in terms of species, especially in places where orchids are concentrated.

The herbage is clearly two-layered. The total projective cover reaches $100 \%$.

The state of the plant community in the deschampsiaalliosum phytocenoses is good; the species stably occupy new territories. Individuals of the species growing near the shrub layer, even with the same soil and vegetation background, are always approximately $10 \mathrm{~cm}$ higher and they have an enlarged inflorescence.

The main limiting factors are ecological and anthropogenic: constant stagnation of water, wind oppression, strong insolation in open areas; haying in the fruiting phase, grazing and trampling by cattle, pulling out for bouquets. With a decrease in anthropogenic load, the population is capable of expanding and occupying new territories.

Equiseto-Carexosum (Equisetum pratense Ehrh., Carex juncella (Fries) Th. Fries) plant community (PC10) was described in the Sibin Basin, in the southeast of the Koktau Mountains, $49.394167^{\circ} \mathrm{N}, 82.721944^{\circ} \mathrm{E}, 904$ m.a.s.l. Plant community is located on the right bank of a small flowing spring.

The herbaceous cover is well developed, it has a high density of up to $0.9-1$ and a total cover of up to $80-95 \%$, but species diversity is poor. The herbage is clearly twolayered. It is represented by mesophilic and mesohygrophilous species. Plant community of sedgehorsetail phytocenoses can be characterized as normal, fullmember, progressive. Diseases and pests were not found. No anomalies were noted.

\section{Kokpekty population}

Kokpekty population of $D$. incarnata is located in the southwestern foothills of the southeastern outskirts of the Kalba ridge, in the northern spurs of the Karazhal mountains. It occupies both banks of the Kokpektinka river valley. Location coordinates: $48^{\circ} 50^{`} \mathrm{~N}, 82^{\circ} 12^{\prime} \mathrm{E}$, 600 m.a.s.1. 


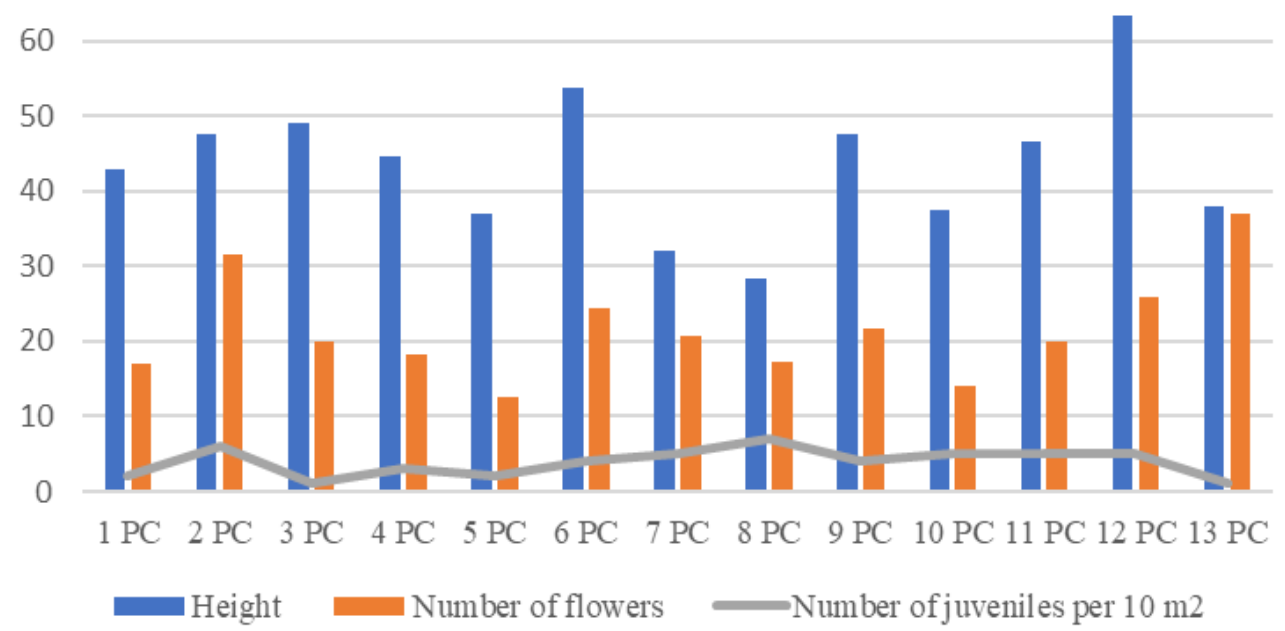

Figure 2. Comparative characteristics of plant height and the number of flowers in the inflorescence

The vegetation cover is with high density and height of herbage, but poor in terms of species-19 species (precisely 19 species). The basis of the phytocenosis is herbaceous species $(84 \%)$, to a lesser extent tree species and shrubs $(16 \%)$. In terms of species diversity, the most numerous families are Fabaceae (26\%), Poaceae (21\%), Salicaceae $(10 \%)$. By ecological confinement, mesophytes prevail $(68 \%)$, mesohygrophytes and xeromesophytes account for $16 \%$ each. The synanthropization coefficient at the level of $42 \%$ indicates a significant degree of anthropogenic load. Within the territory of the Kokpekty population, two main types of phytocenosis have been distinguished. They differentiate by the main dominant species and ecological conditions of the growing areas.

Medicago-Dactylo-Festucosum (Medicago falcata L., Thalictrum simplex L., Dactylis glomerata L., Festuca pratensis Huds.) plant community (PC11). The species occupies a river valley under a forest canopy. Location coordinates: $48.836944^{\circ} \mathrm{N}, 82.202222^{\circ} \mathrm{E}, 620$ m.a.s.l.

The species is settled in small groups of 5-10 individuals. The plant community is located under the canopy Salix viminalis L., S. tenuijulis Ledeb., Betula humilis Schrank, which create diffuse lighting.

The ecological conditions for the growth and development of the species are close to optimal: moderate moisture, partial protection from strong winds, diffused lighting and good humus content of the soil.

The ecotype of $D$. incarnata in forb-grass phytocenoses actively progresses, with a left-sided spectrum, fullmember, with high seed renewal. It is capable of capturing new territories downstream of the river. Diseases are rare. The renewal is predominantly seed.

Carexo-Equiseto-Filipendulo-Festucosum (Carex juncella (Fries) Th. Fries, Equisetum pratense Ehrh., Filipendula ulmaria (L.) Maxim., Festuca pratensis Huds.) plant community (PC12) is located in the eastern part of the Kalba ridge in the southwestern foothills, $48.770556^{\circ} \mathrm{N}$, $82.235278^{\circ} \mathrm{E}, 630$ m.a.s.l. The plant community occupies the territory of forb-grass meadows, in places protected by a canopy of shrubs and Betula humilis Schrank-sp.
The herbaceous composition is well developed, with coverage up to $100 \%$, clearly two-layered.

The state of the species in the phytocenosis is quite good. The species was described at the end of flowering. Generative plants of $D$. incarnata are very large.

In general, the plant community of forb-sedge phytocenoses are stable, slowly developing communities with a high density and competition. The ecotype reproduces mainly by seed and has a high regeneration. According to the complex of natural and climatic conditions and the degree of limiting factors, the plant community is capable of conquering new territories.

\section{Kalbatau population}

Kalbatau population of $D$. incarnata is located in the southwestern spurs of the eastern part of the Kalba highlands, at the foot of the small ridge Saryzhal. The species occupies fragmentary phytocenoses in the Shar river valley, in the vicinity of the Kalbatau village.

The vegetation cover is poor in terms of species; it is formed by 18 species. The main life form is herbaceous vegetation (95\%), shrubs and trees account for 5\%. By the number of species, the most numerous are the following families: Poaceae $(17 \%)$, Fabaceae $(17 \%)$, Rosaceae $(11 \%)$, Ranunculaceae $(11 \%)$. In terms of ecological confinement, mesophytes prevail (67\%), while mesohygrophytes $(22 \%)$ and xeromesophytes $(11 \%)$ are less significant. The synanthropization coefficient of $33 \%$ indicates a significant degree of anthropogenic load. The phytocenoses of Kalbatau population is similar in species composition and ecological conditions.

Equiseto-Carexosum (Equisetum pratense Ehrh, Carex juncella (Fries) Th. Fries) plant community (PC13) is located at $49.190278^{\circ} \mathrm{N}, 81.955833^{\circ} \mathrm{E}, 525 \mathrm{~m} . \mathrm{a} . \mathrm{s} .1$. The relief is leveled and represents a swampy meadow in the lowering of the hills.

The grass stand is well developed, rich in species diversity, and has coverage up to $100 \%$. The dominants are Carex juncella (Fries) Th. Fries-sp-cop ${ }_{1}$, Equisetum pratense 
Ehrh-cop 1, Geranium collinum Steph.-sp, Glycerhiza glabra L.-sp. The grass stand is clearly two-layered.

The species actively populate open, illuminated areas, but is noticeably depressed by insolation and constant wind exposure. As a result, most Dactylorhiza individuals do not exceed the height of the grass stand. Under the canopy of the grass stand, undersized flowering individuals with a shortened stem and a developed inflorescence were noted.

The population of the species actively reproduces both by seed and vegetative methods, but the renewal of the plant community is weak and unsatisfactory. 415 generative individuals were recorded. A notable feature of individuals of this population is rather large inflorescences with well-developed green stipules. Inflorescences are loose, conical or cylindrical-conical in shape. The color variations of the inflorescences range from purple to purple hues.

In general, the plant community of Equiseto-Carexosum phytocenoses is full-member, well-developed, with satisfactory renewal. Despite the extreme conditions, the ecotype occupies new territories and has high competition in the herbage; it is experiencing anthropogenic influence in the form of overgrazing, haymaking before the fruiting phase, pulling out into bouquets.

The flora of $D$. incarnata populations on the Kalba Ridge includes 117 species (Supplement, Table S1), belonging to 30 families and 80 genera. Typical marker species are Thalictrum simplex L., Salix viminalis L., Filipendula ulmaria (L.) Maxim., Sanguisorba officinalis L., Geranium pratense L., Festuca pratensis Huds. The presence of weed species: Humulus lupulus L., Urtica dioica L., Arctium lappa L. confirms the high anthropogenic load on natural phytocenoses.

The floropopulation similarity of the studied populations varies within 9-27\%. The similarity of the species composition (Table 1) is Koktau with Sibin (27\%), Koktau with Kokpekty (13\%), Kokpekty with Kalbatau (9\%), Sibin with Kokpekty (17\%), Sibin with Kalbatau $(20 \%)$. The results of the similarity of phytocenoses also indicate a high ecological plasticity of the species, which, as a result, is able to grow in various types of phytocenoses. Ecologically, in all populations, the basis of phytocenoses is made up of mesophytes (67-75\%), in a lesser proportion there are mesohygrophytes (16-27\%) and xeromesophytes (6-16\%). When comparing the flora of $D$. incarnata populations with the flora of the Kalba Ridge (Table 2), it was found that the families Poaceae Barnhart, Ranunculaceae Juss., Rosaceae Juss., Asteraceae Bercht. and J. Presl. differ in their share of participation in the formation of the species composition. This is due to the greater number of mesophytic and mesohygrophytic species and the low number of xerophytes and petrophytes, indicating that the species is confined to the herb-grass types of communities. Spearman's rank correlation coefficient is 0.837 , i.e., the relationship is direct and strong, and the flora of $D$. incarnata populations in the spectrum of the 10 leading families is quite similar to the flora of the Kalba Ridge.

The high percentage of species in the first ten families $(72.5 \%)$ indicates a high degree of anthropogenic transformation of the flora of $D$. incarnata populations, in contrast to the entire flora of the Kalba Ridge (55.52\%).

The predominant life form is herbaceous species (81$95 \%$ ), the share of shrubs and trees is insignificant (5$19 \%)$.

The characteristics of vitality type of plant communities of D. incarnata, calculated on the basis of morphometric characteristics (Supplement, Table S2), are presented in Table 3. According to the index of vitality of plant community (IVC), a gradient of deterioration of living conditions was calculated, which was built according to a decrease in IVC.

The established gradient of deterioration in the growth conditions of D. incarnata was the following row: PC 12 (1.55)- PC 6 (1.33)- PC 3 (1.22)- PC 2 (1.17)- PC 9 (1.14)- PC 4 (1.09)- PC 1 (1.07)- PC 11 (1.03)- PC 10 (0.94)- PC 13 (0.93)- PC 5 (0.90)- PC $7(0.79)$ - PC 8 (0.69). When assessing the vitality type of plant community using the $\mathrm{Q}$ criterion, it was revealed that most of $\mathrm{D}$. incarnata plant communities are characterized as depressive. The thriving plant communities are CP 1, CP 3, $\mathrm{CP} 6, \mathrm{CP} 7, \mathrm{CP} 12$. In these plant communities, the proportion of individuals of the higher class is from 28 to $55 \%$, and the proportion of individuals of the lower class is from 15 to $27 \%$. Among depressive plant communities, the lowest indicators of vitality (0.69 and 0.90) and Q (4 and 1.5) are characteristic of plant communities 5 and 8 , the highest is CP 9, where these indicators were 1.14 and 2.5.

Comparison of such vitality traits as plant height, the number of flowers in the inflorescence, and the amount of young undergrowth showed a high degree of variation for all plant communities (Figure 2).

\section{Discussion}

The study of the floristic composition of communities with the participation of Orchids has always attracted increased interest. Previously, such work was carried out in neighboring border areas (Egorova and Suleimanova 2021; Shirokov et al. 2020).

Unlike other works on the study of the life strategies of Orchids, where from 1 to 9 plant communities were studied (Ishbirdin et al. 2005; Egorova et al. 2014; Khapugin et al. 2017), in this work, 13 plant communities were used for a more complete study of the state of the species. In addition, in this work, the complete floristic composition of all populations has been established.

The vitality index was chosen as the main indicator in assessing the state of plant communities. This work is partially similar to the work of Egorova (Egorova et al. 2014) and Klymenko (Klymenko and Kovalenko 2016). As in other works on orchids (Chadayeva and Kyarova 2020; Mursal et al. 2020), the ecological gradient for $D$. incarnata also depends to a greater extent on the anthropogenic load on the phytocenosis.

Analysis of the ecological position of $D$. incarnata habitats in relation to moisture content revealed that this species, according to the degree of soil moisture, belongs to stenovalent.

The synanthropization coefficient for the surveyed populations varies within $33-42 \%$, which confirms a 
significant degree of anthropogenic pressure on communities with the participation of D. incarnata. Anthropogenic load is a key limiting factor in the Koktau and Kalbatau populations.

Through analyzing the age composition of the populations, the dynamics and stability of plant communities, it was found that the recovery index is within the optimum. The dominant position is occupied by individuals of the virginal and pregenerative stages of growth.

In the analysis of the field data results, it was found that all populations differ markedly in floristic composition and growing conditions. As a rule, populations are of different ages, full-member, mainly with a left-sided spectrum, with seed renewal. Relatively more difficult growing conditions exist in Carexo-menthuosum, Heteroherbo-gramisum phytocenoses. The cenoecotypes occupy mossy rocks, rubble banks of streams and mountain rivers and have difficulties with the development of young undergrowth. Phytocenosis Filipendulo-Sanguisorbo-Thalictrosum and Carexo-Equiseto-Filipendulo-Festucosum have optimal conditions: overly humid meadows and forest edges with low density and competition. Due to its weak competitive ability, the species settle in different ecological and phytocenotic conditions: wet meadows, flooded forb meadows, damp, excessively wet meadows, steppe moderately moist forb-sedge-grass meadows, mossy placers of stones among tree-shrub vegetation, in meadows canopy Salix viminalis L.

The ecological optimum of the species falls on the southeastern slopes with diffused lighting and moderate wind impact. Self-maintenance and reproduction of the species are carried out mainly by seeds, less often by vegetative division of the finger root.

In conclusion, D. incarnata in Kazakhstan Altai belongs to a monocentric biomorph with partial late nonspecialized disintegration. On the basis of field expedition surveys, 4 main populations were identified, 13 localities were recorded in different ecological and phytocenotic conditions. Ecological and biological analysis confirmed the mesophytic and hygromesophytic nature of the flora of meadow and valley habitats of $D$. incarnata populations. The flora of $D$. incarnata populations on the Kalba Ridge includes 117 species belonging to 30 families and 80 genera.

Populations are of different ages, with left-sided and right-sided spectra, self-maintenance by seed is occasionally vegetatively. Relatively more difficult growing conditions exist in mint-sedge, herb-grass phytocenoses. The ecotypes occupy mossy rocks, rubble banks of streams and mountain rivers and they have difficulties with the development of young undergrowth. The Filipendulo-Sanguisorbo-Thalictrosum and CarexoEquiseto-Filipendulo-Festucosum phytocenoses have optimal conditions: overly humid meadows and forest edges with low density and competition. The species settle in different ecological and phytocenotic conditions: humid meadows, flooded forb meadows, damp, excessively humid meadows, steppe moderately humid forb-sedge-grass meadows, mossy placers of stones among woody-shrubs of vegetation, in meadows under the canopy of Salix viminalis L.

The floral similarity of the studied populations varies within the range of $9-27 \%$. The similarity of the species composition is: Koktau with Sibin (27\%), Koktau with Kokpekty (13\%), Kokpekty with Kalbatau (9\%), Sibin with Kokpekty (17\%), Sibin with Kalbatau (20\%). The results of the similarity of phytocenoses also indicate the high ecological plasticity of the species which is able to grow in various types of phytocenoses. The ecological optimum of the species happens to southeastern slopes with diffuse lighting and moderate wind impact. Self-maintenance and reproduction of the species are carried out mainly by seeds, less often by vegetative division of the finger root.

Due to analysis of the age composition of the populations, the dynamics and stability of plant communities, it was found that the recovery index is within the optimum. The main limiting factors that significantly limit the dispersal of the species are high competition in phytocenoses, anthropogenic load, and strict ecological confinement. The surveyed populations require protection and long-term monitoring of the demographic structure.

\section{ACKNOWLEDGEMENTS}

This article was prepared as part of the project AR05133868 "Study of the distribution and current status of populations of the Orchidaceae family in Kazakhstan Altai and their introduction in the Altai Botanical Garden 2018-2020."

\section{REFERENCES}

Akbulut MK, Şenel G, Şeker ŞS. 2020. Comparison of labellum and spur papillae in Dactylorhiza (Orchidaceae) from Anatolia. Brazilian J Bot 43 (2): 367-377. DOI: 10.1007/s40415-020-00597-5

Balao F, Trucchi E, Wolfe TM, Hao BH, Lorenzo MT, Baar J, Sedman L, Kosiol C, Amman F, Chase MW, Hedrén M, Paun O. 2017. Adaptive sequence evolution is driven by biotic stress in a pair of orchid species (Dactylorhiza) with distinct ecological optima. Mol Ecol 26 (14): 3649-3662. DOI: $10.1111 / \mathrm{mec} .14123$

Bateman RM, Rudall PJ. 2006. Evolutionary and morphometric implications of morphological variation among flowers within an inflorescence: A case-study using European orchids. Ann Bot 98: 975-993. DOI: 10.1093/aob/mcl191

Brandrud MK, Baar J, Lorenzo MT, Athanasiadis A, Bateman RM, Chase MW, Hedrén M, Paun O. 2020. Phylogenomic relationships of diploids and the origins of allotetraploids in Dactylorhiza (Orchidaceae). Syst Biol 69 (1): 91-109. DOI: 10.1093/sysbio/syz035

Chadayeva VA, Kyarova GA. 2020. State of cenopopulations of Platanthera chlorantha (Custer) Rchb. (Orchidaceae) under anthropogenic loads on forest and meadline phytocenoses of the Central Caucasus. Soc-ecol Technol 4: 411-428. DOI: 10.31862/2500-2961-2020-10-4-411-428. [Russian]

De Hert K, Jacquemyn H, Van Glabeke S, Roldán-Ruiz I, Vandepitte K, Leus L, Honnay O. 2012. Reproductive isolation and hybridization in sympatric populations of three Dactylorhiza species (Orchidaceae) with different ploidy levels. Ann Bot 109 (4): 709-720. DOI: 10.1093/aob/mcr305.

Braunschmid H, Guilhot R, Dötterl S. 2021. Floral scent and pollinators of Cypripedium calceolus L. at different latitudes. Diversity 13 (1): 5. DOI: $10.3390 / \mathrm{d} 13010005$.

Drude O. 1913. Die Ökologie der Pflanzen. F. Vieweg and Sohn, Braunschweig. [German] 
Egorova NY, Suleimanova VN. 2021. Variability of morphological structures in Cypripedium calceolus (Orchidaceae) and their relationship with the habitat conditions in the southern taiga ecosystems, Russia. Nat Conserv Res 6(1): 28-41. DOI: 10.24189/ncr.2021.006. [Russian]

Egorova NY, Suleimanova VN, Egoshina TL. 2014. State of Platanthera bifolia (Orchidaceae) cenopopulations in Kirov region. Plant Resour 50 (3): 398. [Russian]

Efimov PG, Philippov EG, Krivenko DA. 2016. Allopolyploid speciation in Siberian Dactylorhiza (Orchidaceae, Orchidoideae). Phytotaxa 258 (2): 101-120. DOI: 10.11646/phytotaxa.258.2.1.

Efimov PG. 2020. Orchids of Russia: Annotated checklist and geographic distribution. Nat Conserv Res 5 (1): 1-18. DOI: 10.24189/ncr.2020.018.

Füller F. 1972. Die Gattungen Orchis und Dactylorhiza. Die Orchideen Deutschlands, 3. Wittenberg. A. Ziemsen. [German]

Givnish TJ, Spalink D, Ames M, Lyon SP, Hunter SJ, Zuluaga A, Iles WJD, Clements MA, Arroyo MTK, Leebens-Mack J, Endara L, Kriebel R, Neubig KM, Whitten WM, Williams NH, Cameron KM. 2015. Orchid phylogenomics and multiple drivers of their extraordinary diversification. Proc R Soc B 282: 20151553. DOI: 10.1098/rspb.2015.1553.

Hedrén M. 2001. Conservation priorities in Dactylorhiza, a taxonomically complex genus. Lindleyana 16 (1): 17-25.

Hedrén M, Paun O, Sayers B. 2011. The polymorphic early marsh orchids, Dactylorhiza incarnata sl (Orchidaceae), at Lough Gealain, Ireland. New J Bot 1 (1): 16-23. DOI: 10.1179/204234811X577817.

Ilminskikh NG, Zhukov AY. 2020. Modern synanthropization of flora and conservation of biodiversity. World Science 2020. Problems and Prospects. [Russian].

Ishbirdin AR, Ishmuratova MM. 2004. Adaptive morphogenesis and ecological-cenotic survival strategies of herbaceous plants. In Methods of Population Biology. Collection of Materials VII AllRussian Population Seminar (Syktyvkar, February 16-21, 2004), Part 2. Syktyvkar, Komi Scientific Center of the Ural Branch of the Russian Academy of Sciences. [Russian]

Ishbirdin AR, Ishmuratova MM, Zhirnova TV. 2005. Life strategies of the cenopopulation Cephalanthera rubra (L.) Rich. on the territory of the Bashkir State Reserve. Bulletin of the Nizhny Novgorod University. NI Lobachevsky. Series: Biol 1: 85-98

IUCN. 2020. The IUCN red list of threatened species, version 2020 IUCN Red List Unit, Cambridge, U.K. http://www.iucnredlist.org

Jaccard P. 1901. Distribution de la flore alpine dans le Bassin des Dranses et dans quelques regions voisines. Bull Soc Vaudoise Sci Nat 37 (140): 241-272. [French]

Jersáková J, Traxmandlová I, Ipser Z, Kropf M, Pellegrino G, Schatz B, Djordjević V, Kindlmann P, Renner SS. 2015. Biological flora of Central Europe: Dactylorhiza sambucina (L.) Soó. Perspectives Plant Ecol Evol Syst 17 (4): 318-329. DOI: 10.1016/j.ppees.2015.04.002

Juskiewicz-Swarczyna B, Endler Z, Slomka W. 2006. Secondary expansion of Dactylorhiza incarnata (L.) Soo in formerly arable areas in Northeastern Poland. J Eur Orch 38 (2): 287-288.

Kaki A, Vafaee Y, Khadivi A. 2020. Genetic variation of Anacamptis coriophora, Dactylorhiza umbrosa, Himantoglossum affine, Orchis mascula, and Ophrys schulzei in the western parts of Iran. Industrial Crops Prod 156: 112854. DOI: 10.1016/j.indcrop.2020.112854.

Khapugin AA. 2020. A global systematic review on orchid data in Protected Areas. Nat Conserv Res 5 (1): 19-33. DOI: 10.24189/ncr.2020.019.

Khapugin AA, Chugunov GG, Vargot EV. 2017. Cypripedium calceolus (Orchidaceae) in central Russia: A case study for its populations in two protected areas in the Republic of Mordovia (Russia). Lankesteriana 17 (3): 417-431. DOI: 10.15517/lank.v17i3.31577,

Klymenko AA, Kovalenko IN. 2016. Basic approaches to determining stability of rare plant species populations. Studia Biologica 10 (2): 123-132.

Kotukhov YuA, Danilova AN, Anufriyeva OA, Suleimenov AN, Sumbembayev AA, Kubentaev SA. 2018. Ecological and biological features of Cypripedium at Katon-Karagay State National Natural Park. Plant Arch 18 (2): 1499-1502.

Kubentayev SA, Efimov PG, Alibekov DT. 2021. Historical records of Neottia cordata and Hammarbya paludosa, new in the Kazakhstan flora. Nat Conserv Res 6 (2): 103-105. DOI: 10.24189/ncr.2021.032

Mursal N, Mehdiyeva NP, Ibrahimova AG. 2020. Population status and ecology of Platanthera chlorantha (Orchidaceae) in the greater
Caucasus (Azerbaijan). Nat Conserv Res 5 (1): 114-124. DOI: 10.24189/ncr.2020.046.

Naczk AM, Kowalkowska AK, Wisniewska N, Halinski LP, Kapusta M, Czerwicka M. 2018. Floral anatomy, ultrastructure and chemical analysis in Dactylorhiza incarnata/maculata complex (Orchidaceae). Bot J Linn Soc 187: 512-536. DOI: 10.1093/botlinnean/boy027.

Naczk AM, Chybicki IJ, Zietara MS. 2016. Genetic diversity of Dactylorhiza incarnata (Orchidaceae) in northern Poland. Acta Societatis Botanicorum Poloniae 85 (2): 3496. DOI 10.5586/asbp.3496.

Naczk AM, Górniak M, Szlachetko DL, Ziętara MS. 2015. Plastid DNA haplotype diversity and morphological variation in the Dactylorhiza incarnata/maculata complex (Orchidaceae) in northern Poland. Bot J Linnean Soc 178 (1): 121-137. DOI: 10.1111/boj.12267.

Nevzorov AV, Smirnova EB, Sergeeva IV, Ponomareva AL, Shevchenko EN. 2019. Ontogenetic structure of cenopolulations of Orchis militaris L. and Dactylorhiza incarnata (L.) Soo (Orchidaceae, Liliopsida) in Romanovskii District of Saratov Region. Biol Bull 46 (10): 1426-1430. DOI DOI: 10.1134/S1062359019100224.

Nordström S, Hedrén M. 2009. Evolution, phylogeography and taxonomy of allopolyploid Dactylorhiza (Orchidaceae) and its implications for conservation. Nordic J Bot 27 (6): 548-556. DOI: 10.1111/j.17561051.2009.00548.x.

Paun O, Bateman RM, Fay MF, Luna JA, Moat J, Hedrén M, Chase MW. 2011. Altered gene expression and ecological divergence in sibling allopolyploids of Dactylorhiza (Orchidaceae). BMC Evol Biol 11: 113. DOI: $10.1186 / 1471-2148-11-113$.

Pillon Y, Fay M, Shipunov A, Chase M. 2006. Species diversity versus phylogenetic diversity: A practical study in the taxonomically difficult genus Dactylorhiza (Orchidaceae). Biol Conserv 129: 4-13. DOI: 10.1016/j.biocon.2005.06.036

Pillon Y, Qamaruz-Zaman F, Fay MF, Hendoux F, Piquot Y. 2007. Genetic diversity and ecological differentiation in the endangered fen orchid (Liparis loeselii). Conserv Genet 8: 177. DOI: 10.1007/s10592-006-9160-7.

Popovich AV, Averyanova EA, Shagarov LM. 2020. Orchids of the Black Sea coast of Krasnodarsky Krai (Russia): Current state, new records, conservation. Nat Conserv Res 5 (1): 46-68. DOI: $10.24189 /$ ncr.2020.047

Qgis. Version 3.12.0-București software (https://download.qgis.org).

Schrautzer J, Fichtner A, Huckauf A, Rasran L, Jensen K. 2011. Longterm population dynamics of Dactylorhiza incarnata (L.) Soó after abandonment and re-introduction of mowing. Flora-Morph Distrib Funct Ecol Plants 206 (7): 622-630. DOI: 10.1016/j.flora.2010.11.008.

Scmeidt O. 1996. Estimaa Orchideed. Varrak, Tallin. [Estonian]

Shirokov AI, Syrova VV, Kryukov LA, Shtarkman NN, Shestakova AA. 2017. Reintroduction of Dactylorhiza incarnata (L.) Soó into the natural habitats of the European Russia. Appl Ecol Environ Res 15 (1): 445-455. DOI: 10.15666/aeer/1501 445455.

Shirokov AI, Syrova VV, Salokhin AV, Markelov IN, Andronova EV, Ganyushkina EV. 2020. Conservation issues and infraspecific polymorphism of Cypripedium guttatum on selected locations in Russia. Nat Conserv Res 5 (1): 145-154. DOI: 10.24189/ncr.2020.054

Shipunov AB, Bateman RM. 2005. Geometric morphometrics as a tool for understanding Dactylorhiza (Orchidaceae) diversity in European Russia. Biological J Linn Soc 85: 1-12. DOI: 10.1111/j.10958312.2005.00468.x

Shipunov AB, Fay MF, Pillon Y, Bateman RM, Chase MW. 2004. Dactylorhiza (Orchidaceae) in European Russia: Combined molecular and morphological analysis. Am J Bot 91 (9): 1419-1426. DOI: 10.3732/ajb.91.9.1419.

Shipunov A, Efimov P. 2015. "Northern tetraploids" clarified: A study of dactylorchids (Dactylorhiza, Orchidaceae) from North European Russia. Flora-Morph Distrib Funct Ecol Plants 215: 40-45. DOI: 10.1016/j.flora.2015.07.005

Statistica 64. Version 10 (Copyright: StatSoft, Inc. 1984-2011, https://www.tibco.com/products/data-science).

Sumbembayev AA, Danilova AN, Abugalieva SI. 2020. List of Orchidaceae family of the Kazakhstan part of the Altai Mountains. Exp Biol 82 (1): 87-94. DOI: DOI: 10.26577//eb.2020.v82.i1.07.

Swarts DN, Dixon WD. 2009. Terrestrial orchid conservation in the age of extinction. Ann Bot 104: 543-556. DOI: 10.1093/aob/mcp025

Takhtajan A. 2009. Flowering Plants, Second edition. Springer., Nederland

The Plant List. 2020. Version 1.1. http://www.theplantlist.org/ 
Tsiftsis S, Tsiripidis I, Karagiannakidou V, Alifragis D. 2008. Niche analysis and conservation of the orchids of east Macedonia (NE Greece). Acta Oecologica 33 (1): 27-35. DOI: 10.1016/j.actao.2007.08.001.

Vallius E, Lammi A, Kuitunen M. 2007. Reproductive success of Dactylorhiza incarnata ssp. incarnata (Orchidaceae): The effects of population size and plant visibility. Nordic J Bot 25 (3-4): 183-189. DOI: 10.1111/j.0107-055X.2007.00051.x.

Wani IA, Verma S, Mushtaq S, Alsahli AA, Alyemeni MN, Tariq M, Pant S. 2021. Ecological analysis and environmental niche modelling of Dactylorhiza hatagirea (D. Don) Soo: A conservation approach for critically endangered medicinal orchid. Saudi J Biol Sci 28 (4): 2109 2122. DOI: 10.1016/j.sjbs.2021.01.054.
WCSP. 2020. World Checklist of Selected Plant Families. Facilitated by the Royal Botanic Gardens, Kew. http://wcsp.science.kew.org/

Wróblewska A, Szczepaniak L, Bajguz A, Jęrzejczyk I, Tałałaj I, Ostrowiecka B, Brzosko E, Jermakowicz E, Mirski P. 2019. Deceptive strategy in Dactylorhiza orchids: Multidirectional evolution of floral chemistry. Ann Bot 123 (6): 1005-1016. DOI: 10.1093/aob/mcz003.

Zheleznaya EL. 2009. Changes in the structure of a Dactylorhiza incarnata (L.) Soó population during the overgrowing of a meadowbog community complex in the Moscow region. Russian J Ecol 40 (1): 39-43. DOI: 10.1134/S1067413609010068

Zlobin Y. 1989. Principles and Methods of Cenotic Plant Populations. Izdatel'stvo Kazanskogo universiteta, Kazan'. [Russian] 
Table S1. The flora of Dactylorhiza incarnata populations on the Kalba Ridge, Kazakhstan

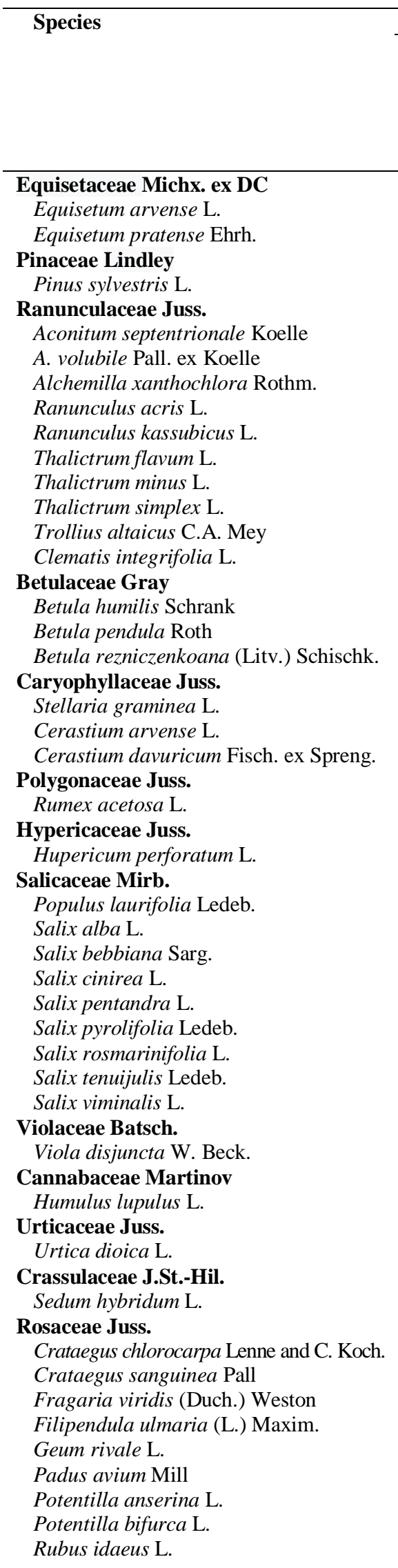

Rubus saxatilis L.

Sanguisorba officinalis L.

Fabaceae Lindl.

Amoria hibrida (L.) C. Pesl.

Amoria repens (L.) C. Presl.

Lathyrus pratensis $\mathrm{L}$.

Lupinaster pentaphyllus Moench

Medicago falcata $\mathrm{L}$.

Melilotus albus Medik.

Glycerhiza glabra L.

Trifolium pratense $\mathrm{L}$.

Vicia sepium L.

Geraniaceae Juss.

Geranium collinum Steph.

Geranium pratense L.

Adoxaceae E.Mey.

Viburnum opulus L.

Apiaceae Lindl.

Angelica archangelica L.

Angelica decurrens (Ledeb.) B. Fedtsch.

Antriscus sylvestris

Bupleurum longifolium L. subsp. aureum

(Fisch. ex Hoffm.) Soo

Carum carvi $\mathrm{L}$.

Asteraceae Bercht. and J.Presl.

Arctium lappa L.

Artemisia austriaca Jacq.

Artemisia tanacetifolia $\mathrm{L}$.

Artemisia vulgaris $\mathrm{L}$.

Cacalia hastata $\mathrm{L}$.

Cirsium incanum (S.G. Gmel.) Fisch.

Inula helenium $\mathrm{L}$.

Ligularia glauca (L.) O. Hoffm.

Serratula coronata L.

Sonchus arvensis $\mathrm{L}$.

Tephroseris integrifolia (L.) Holub.

Rubiaceae Juss.

Galium boreale L.

Galium verum $\mathrm{L}$.

Convolvulaceae Juss.

Convolvulus arvensis $\mathrm{L}$.

Boraginaceae Juss.

Myosotis palustris (L.) L.

Pulmonaria mollis Wulf. Ex Hornem.

Scrophulariaceae Juss.

Rhinanthus songaricus (Sterneck) B.

Fedtsch.

Plantaginaceae Juss.

Plantago media L.

Veronica anagalis-aquatica $\mathrm{L}$.

Veronica longifolia $\mathrm{L}$.

Lamiaceae Martinov

Lamium album L.

Mentha asiatica Boriss.

Phlomoides tuberosa (L.) Moench.

Melanthiaceae Batsch ex Borkh.

Veratrum lobelianum Bernh.

Orchidaceae Juss.

Dactylorhiza incarnata (L.) Soo

D. maculata (L.) Soo

Alliaceae J.G. Agardh

Allium hymenorchizum Ledeb.

Allium nutans L.

Allium shoenoprasum L.

Juncaceae Juss.

Juncus compressus Jacq.

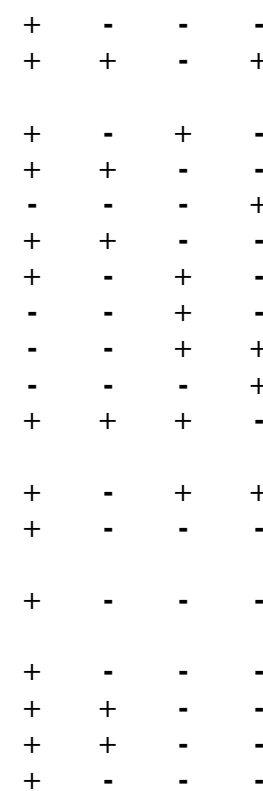

$\begin{array}{llll}+ & - & - & - \\ + & - & - & - \\ - & + & - & - \\ + & - & - & - \\ + & - & - & - \\ + & + & - & - \\ - & - & - & + \\ + & - & - & - \\ + & - & - & - \\ - & + & - & - \\ + & - & - & -\end{array}$

$\begin{array}{llll}+ & - & - & - \\ + & - & - & -\end{array}$

$\begin{array}{cccc}- & - & + & - \\ + & - & - & - \\ + & - & - & - \\ - & - & - & +\end{array}$

$\begin{array}{llll}+ & + & - & + \\ + & - & - & - \\ + & + & - & - \\ + & - & - & - \\ + & + & - & - \\ + & - & - & - \\ + & + & - & - \\ + & + & + & + \\ - & + & - & - \\ & & & \\ - & + & - & - \\ + & - & - & - \\ - & + & - & - \\ + & + & - & -\end{array}$ 


\section{Cyperaceae Juss.}

Carex disticha Huds.

Carex humilus Leyss.

Carex juncella (Fries) Th. Fries

Carex macroura Meinsh.,

Scirpus silvaticus $\mathrm{L}$.

Poaceae Barnhart

Alopecurus glaucus Less.

Alopecurus pratensis L.

Bromopsis inermis (Leyss.) Holub Calamagrostis epigeios (L.) Roth Dactylis glomerata L.

Deschampsia cespitosa (L.) Beauv.

Eleocharis palustris (L.) Roem. \& Schult.
Elymus caninus (L.) L.

$\begin{array}{lllll}+ & + & - & - & \text { Elymus sibiricus L. } \\ + & - & - & - & \text { Elytrigia repens (L.) Nevski }\end{array}$

Festuca altissima All.

Festuca pratensis Huds.

Hordeum bogdanii Wilensky

Koeleria cristata (L.) Pers.

- + - - Melica nutans L.

$+\quad+\quad+\quad$ Poa angustifolia $\mathrm{L}$.

$+\quad-\quad$ - $\quad$ - Poa palustris L.

$+\quad+\quad-\quad$ Poa pratensis L.

$+\quad+\quad$ - $\quad$ Poa remota Forsell.

$+\quad+\quad-\quad-\quad$ Stipa pennata L. \begin{tabular}{llll}
+ & - & - & - \\
+ & - & - & - \\
+ & + & - & - \\
+ & - & - & - \\
- & + & + & + \\
- & - & - & + \\
- & + & - & - \\
+ & - & - & - \\
+ & - & - & - \\
+ & + & + & - \\
- & + & - & - \\
+ & - & - & - \\
+ & - & - & - \\
\hline
\end{tabular} 
Table S2. Morphometric characteristics of Dactylorhiza incarnata

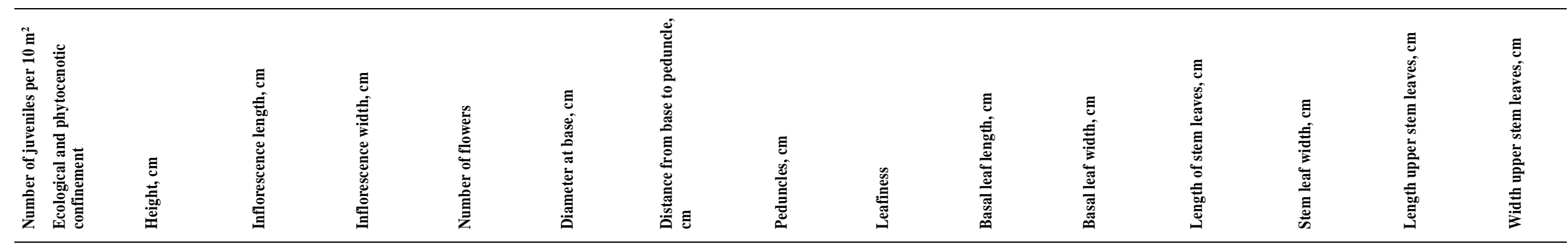

Koktau population

Carexo-menthum (Carex macroura Meinsh, Mentha asiatica Boriss), CP1

2 The foot of the northwestern slope, the valley of a mountain stream, heavily overgrown with tree and shrub species. Stones are covered with a thin layer of moss.
$35-52$
$\dot{\mathrm{x}}=43$
$7-14$
$\dot{\mathrm{x}}=10.25$
$2.5-3$
$\dot{x}=2.6$
$10-24 \quad$ to 0.8
$16-27$
$\dot{x}=23$
$5-12$
$\dot{x}=8.25$
$\begin{array}{ll}4-5 & 9-11 \\ \dot{\mathrm{x}}=9.75 & \end{array}$
$\dot{\mathrm{x}}=9.75 \quad \begin{array}{ll}2-3 \\ \mathrm{x}=2.5\end{array}$
$8-18$
$\dot{\mathrm{x}}=12$
$1-3$
$3-8$
$\dot{x}=5$
$0.7-1.5$

Filipendulo-Sanguisorbo-Thalictrosum

Filipendula ulmaria (L.) Maxim., Sanguisorba officinalis L., Thalictrum minus L.), CP2

6 Meadow glade, covered from all sides by pine trees (Pinus sylvestris L.). In small groups, in abundantly moist, exposed areas.

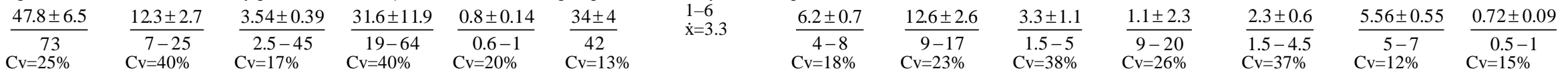

Scirpo-Poesum (Scirpus sylvaticus L., Poa palustris L.), CP3

1 Glade in a hollow with excessive moisture on abundantly humic mountain meadow chernozems.

$$
\begin{array}{llllll}
49 \pm 9 & 10.2 \pm 2.9 & 3.2 \pm 0.4 & 20 \pm 3 & 0.63 \pm 0.08 & 31.5 \pm 2.7
\end{array}
$$

\begin{tabular}{|c|c|c|c|c|c|c|c|c|c|c|c|c|}
\hline $49 \pm 9$ & $10.2 \pm 2.9$ & $3.2 \pm 0.4$ & $20 \pm 3$ & $0.63 \pm 0.08$ & $31.5 \pm 2.7$ & $9.9 \pm 2.5$ & $9.2 \pm 2.6$ & $2.4 \pm 0.7$ & $\begin{array}{l}12-14 \\
\dot{x}-13\end{array}$ & $2.2 \pm 0.6$ & $\begin{array}{l}2-8 \\
\dot{x}=44\end{array}$ & $0.83 \pm 0.4$ \\
\hline $\begin{array}{c}35-62 \\
\mathrm{Cv}=21 \%\end{array}$ & $\begin{array}{r}6.5-14 \\
\mathrm{Cv}=28 \%\end{array}$ & $\begin{array}{r}2.5-3.5 \\
\mathrm{Cv}=13 \%\end{array}$ & $\begin{array}{c}15-24 \\
\mathrm{Cv}=19 \%\end{array}$ & $\begin{aligned} & 0.5-0.7 \\
& \mathrm{Cv}=13 \%\end{aligned}$ & $\begin{array}{r}35 \\
\mathrm{Cv}=8 \%\end{array}$ & $\begin{array}{r}4.5-16 \\
\mathrm{Cv}=35 \%\end{array}$ & $\begin{aligned} 6 & -14 \\
\mathrm{Cv} & =28 \%\end{aligned}$ & $\begin{array}{r}1.5-3.5 \\
\mathrm{Cv}=30 \%\end{array}$ & & $\begin{array}{r}1.5-3 \\
\mathrm{Cv}=28 \%\end{array}$ & & $0.4-1.5$ \\
\hline
\end{tabular}

Heteroherbo-gramisum (Elytrigia repens (L.) Nevski, Poa angustifolia L., Fragaria virides (Duch.) Weston, Ranunculus acris L., Galium verum L.), CP4

3 A ridge on closed mattress granitoids, well protected from wind and insolation from the southwest direction (Pinus sylvestris L., Populus laurifolia Ledeb.)

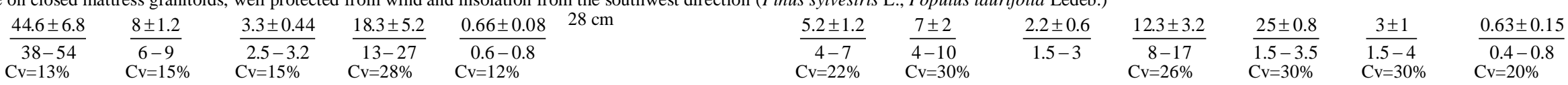

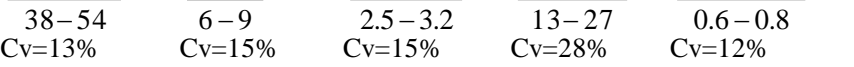

Filipendulo-Equisetosum (Filipendula ulmaria (L.) Maxim., Equisetum arvense L.), CP5

\begin{tabular}{|c|c|c|c|c|c|c|c|c|c|c|c|c|c|}
\hline $53.69 \pm 3.51$ & $4-8$ & $2.94 \pm 0.23$ & $12-49$ & $0.58 \pm 0.04$ & $36.5 \pm 6$ & $5 \pm 1.05$ & $4-6$ & $6.3 \pm 1.4$ & $2.2 \pm 0.25$ & $9.75 \pm 2.63$ & $2.12 \pm 0.34$ & $2.91 \pm 0.49$ & $0.53 \pm 0.1$ \\
\hline $\begin{array}{r}42-60 \\
\mathrm{Cv}=10.8 \%\end{array}$ & & $\begin{array}{r}2.5-3.5 \\
\mathrm{Cv}=10.2 \%\end{array}$ & & $0.5-0.7$ & $\begin{array}{r}26-43 \\
\mathrm{Cv}=18 \% \\
\end{array}$ & $\begin{array}{c}3-7 \\
\mathrm{Cv}=29.8 \%\end{array}$ & & $\begin{array}{c}5-9 \\
\mathrm{Cv}=21 \%\end{array}$ & $\begin{array}{c}2-2.5 \\
\mathrm{Cv}=11.5 \%\end{array}$ & $\begin{array}{c}7-11 \\
\mathrm{Cv}=19.4 \%\end{array}$ & $\begin{array}{c}2-2.5 \\
\mathrm{Cv}=11.7 \%\end{array}$ & $\begin{array}{c}2-3.5 \\
\mathrm{Cv}=16.8 \%\end{array}$ & $\overline{0.4-0.7}$ \\
\hline
\end{tabular}

2 Forb-grass community. A narrow strip in the coastal part of the southwestern slope.

$$
\begin{array}{llllll}
29-48 & 3-7.5 & 2-3 & 9-15 & 0.4-0,6 & 19-32 \\
\dot{\mathrm{x}}=37 & \dot{\mathrm{x}}=5.1 & \dot{\mathrm{x}}=2.5 & \dot{\mathrm{x}}=12.5 & \dot{\mathrm{x}}=0.5 & \dot{\mathrm{x}}=25.75
\end{array}
$$

$\begin{array}{ll}11 & 1.5-3 \\ \dot{x}=2.12\end{array}$

$\stackrel{10-14}{10}$

$1-3$
$\dot{x}=1.95$

$1.5-4$
$\dot{x}=3.6$

Deschampsio-Carexosum (Deschampsia cespitosa (L.) Beauv., Carex humilus Leyss.), CP6

4 In the valley of the stream in the composition of forb meadows. A hollow with a leaking key. 
Carexo-Calamagrostosum (Carex disticha Huds, Calamagrostis epigeous (L.) Roth.), CP7

Water meadows. The species is located in small groups along the stream valley.

$\begin{array}{llllll}\frac{32 \pm 6}{26-43} & \frac{9.2 \pm 1.7}{6.5-13} & \frac{2.87 \pm 0.22}{2.5-3.5} & \frac{20.7 \pm 3.9}{14-28} & \frac{0.7 \pm 0.05}{0.8} & 25-32 \\ \mathrm{Cv}=29 \% & \mathrm{Cv}=24 \% & \mathrm{Cv}=11 & \mathrm{Cv}=22 \% & \mathrm{Cv}=9.4 \%\end{array}$

$3-5$

$$
\frac{5.33 \pm 1.03}{4-7}
$$

$\frac{11.75 \pm 4.5}{4-15}$

$\frac{1.75 \pm 0.56}{1-3}$

$\frac{15.38 \pm 0.76}{12-19}$

$\frac{1.9 \pm 0.3}{1.5-2.5}$

$\frac{3.43 \pm 1.1}{1.5-4.5}$

$1.5-4.5$
$\mathrm{Cv}=35 \%$

$\underline{0.55 \pm 0.1}$

Sanguisorbo-Carexosum (Sanguisorba officinalis L., Carex disticha Jacq.), CP8

7 Open flooded forb meadows.

$$
\frac{28.4 \pm 7.65}{24-40} \quad \begin{array}{ccccccc}
\begin{array}{c}
7.33 \pm 2.94 \\
\mathrm{Cv}=40 \%
\end{array} & \frac{2.5 \pm 0.3}{2-3} & \frac{17.16 \pm 6}{\mathrm{Cv}=12 \%} & \begin{array}{c}
14-30 \\
\mathrm{Cv}=36 \%
\end{array} & \begin{array}{c}
0.62 \pm 0.16 \\
\mathrm{Cv}=25.9 \%
\end{array} & \frac{18 \pm 4}{14-25} & \frac{3.41 \pm 1.35}{\mathrm{Cv}=22 \%} \\
\begin{array}{c}
\mathrm{Cv}=39 \% \\
1.5-5
\end{array}
\end{array}
$$

$\underline{7.66 \pm 2.73}$

$4-12$
-12

$\frac{1.75 \pm 0.52}{1-2.5}$

$\frac{8.5 \pm 1.64}{7-11}$

$\frac{1.9 \pm 0.2}{1.5-2}$

$1.5-2$
$C v=10.65 \%$

$\frac{4.5 \pm 1.5}{2-7}$

$\mathrm{Cv}=39 \%$

$\frac{0.9 \pm 0.3}{0.5-1.5}$

$\mathrm{Cv}=39 \%$

Deschampsio-Alliosum (Deschampsia cespitosa (L.) Beauv., Allium shoenoprasum L.), CP9

$\begin{array}{ccccccc}\frac{47.5 \pm 3.9}{38-70} & \frac{11.6 \pm 1.3}{6-16} & \frac{2.55 \pm 0.31}{2-3.5} & \frac{21.8 \pm 3.2}{18-30} & \frac{0.77 \pm 0.09}{1} & \frac{33.45 \pm 3.52}{25-40} & \frac{5.04 \pm 1.23}{3-5} \\ \mathrm{Cv}=17 \% & \mathrm{Cv}=23 \% & \mathrm{Cv}=23.8 \% & \mathrm{Cv}=18.2 \% & \mathrm{Cv}=15.5 \% & \mathrm{Cv}=15 \% & \mathrm{Cv}=37 \%\end{array}$

\section{$\frac{9.37 \pm 2.62}{6.5-13} \quad \frac{2.68 \pm 0.56}{2-3.5} \quad \frac{14.3 \pm 1.96}{9.5-18}$ \\ $\mathrm{Cv}=34 \%$ \\ $\mathrm{Cv}=25 \%$}

$\frac{2.81 \pm 0.48}{2-3.5}$ $2-3.5$
$\mathrm{Cv}=20.9 \%$ $\frac{4.75 \pm 1.07}{3-7} \quad \frac{0.91 \pm 0.21}{0.7-1.5}$

Equiseto-Carexosum (Equisetum pratense Ehrh.,Carex juncella (Fries) Th. Fries), CP10

$$
\begin{aligned}
& \begin{array}{c}
37.5 \pm 3.5 \\
32-47 \\
\mathrm{Cv}=14 \%
\end{array} \\
& \frac{5.57 \pm 1.3}{4-6} \\
& \frac{2.4 \pm 0.25}{2-3} \\
& \frac{14.1 \pm 3.1}{10-23} \quad \frac{0.54 \pm 0.1}{0.5-0.7} \quad \frac{25 \pm 2.1}{21-28}
\end{aligned}
$$

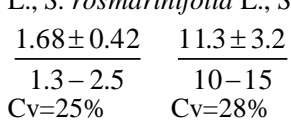

Salix pyrolifolia Ledeb.

Kokpekty population

5 River valley, under the canopy Salix viminalis L., S. Thanuijulis Ledeb., Betula humilis Schrank.

$$
\begin{aligned}
& \frac{46.5 \pm 7.1}{38-59} \\
& \frac{10.5 \pm 2.2}{6-14} \\
& \begin{array}{ll}
\frac{2.87 \pm 0.25}{2.5-3.5} & \frac{20 \pm 4.1}{13-25} \\
\mathrm{Cv}=10.8 \% & \mathrm{Cv}=20 \%
\end{array} \\
& \frac{0.66 \pm 0.15}{0.5-0.9} \\
& \frac{25.4 \pm 0.02}{21-29} \\
& \frac{10.1 \pm 1.6}{7-11}
\end{aligned}
$$

$\frac{5 \pm 1.4}{3-8}$
$\mathrm{Cv}=32 \%$

Carexo-Equiseto-Filipendulo-Festucosum (Carex juncella (Fries) Th. Fries, Equisetum pratense Ehrh., Filipendula ulmaria (L.) Maxim., Festuca pratensis Huds.), CP12

5 A herb-grass meadow, in places protected by a canopy of shrubs and Betula humilis Schrank.
$\frac{63.4 \pm 8.3}{43-83}$

\begin{tabular}{|c|c|c|c|c|c|c|c|c|c|c|c|c|c|}
\hline $38 \pm 5.8$ & $15.8 \pm 3.4$ & $3.1 \pm 0.3$ & $23-55$ & $0.81 \pm 0.11$ & $22 \pm 3.9$ & $3.2 \pm 0.9$ & $6.42 \pm 1.02$ & $1.5-11$ & $2.28 \pm 0.81$ & $10.5 \pm 2.8$ & $3.5 \pm 0.85$ & $4.57 \pm 0.75$ & $0.9 \pm 0.2$ \\
\hline $\begin{array}{r}29-41 \\
\mathrm{Cv}=17 \%\end{array}$ & $\begin{array}{r}6-33 \\
\mathrm{Cv}=28 \%\end{array}$ & $\begin{array}{r}2.5-4 \\
\mathrm{Cv}=12 \%\end{array}$ & & $\begin{array}{c}0.6-1 \\
\mathrm{Cv}=15.5 \%\end{array}$ & $\begin{array}{r}14-29 \\
\mathrm{Cv}=20 \%\end{array}$ & $\begin{array}{c}5 \\
\mathrm{Cv}=34 \%\end{array}$ & $\begin{array}{c}5-8 \\
\mathrm{Cv}=17.8 \%\end{array}$ & & $1.5-3$ & $\begin{array}{r}7-17 \\
\mathrm{Cv}=29 \%\end{array}$ & $\begin{array}{c}2-5 \\
\mathrm{Cv}=27.3 \%\end{array}$ & $\begin{array}{r}3.5-6 \\
\mathrm{Cv}=18.4 \%\end{array}$ & $\begin{array}{r}0.6-1.3 \\
C v=26 \%\end{array}$ \\
\hline
\end{tabular}
$\frac{14.3 \pm 4}{10-16}$
$\frac{3 \pm 0.5}{2-4}$
$\frac{26 \pm 4}{19-47}$
$0.6 \pm 1.2$
$\dot{x}=0.75 \pm 0.1$
$\frac{43.6 \pm 5.99}{38-53}$
$\begin{array}{cc}\frac{6.64 \pm 1.7}{3.5-9} & \frac{6.5 \pm 1.2}{5-8} \\ \mathrm{Cv}=29 \% & \mathrm{Cv}=18 \%\end{array}$
$\frac{8.66 \pm 3.44}{4-13}$
$\mathrm{Cv}=39 \%$
$2.33 \pm 0.68$
$2-3.5$
$C v=29.2 \%$

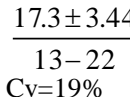
$\frac{2.46 \pm 0.66}{1.88-3.5}$
$\underline{4.2 \pm 0.9}$
$2-7$
$\mathrm{Cv}=32 \%$
$\underline{0.65 \pm 0.2}$
$\mathrm{Cv}=31 \% \quad \mathrm{Cv}=13.7 \%$
Cve $=39 \%$
$\mathrm{Cv}=29.2 \% \quad \mathrm{Cv}=19 \%$
$\mathrm{Cv}=32 \%$

\section{Kalbatau population}

(Equisetum pratense Ehrh, Carex juncella (Fries) Th. Fries), CP13 